\title{
European environmental governance and the post-ecology perspective: a critical analysis of the Water Framework Directive
}

\author{
Fausto Di Quarto $\cdot$ Andrea Zinzani
}

Accepted: 28 February 2021 / Published online: 16 March 2021

(C) The Author(s) 2021

\begin{abstract}
In the framework of critical geographies of the environment, this paper discusses European environmental governance and reflects on its policies, practices and discourses. In this context, we analyze the Water Framework Directive (WFD) as a key, ground-breaking policy aimed at reconfiguring European water governance by foregrounding principles of sustainability and participation. By adopting a political ecology approach and the post-ecology analytical perspective, this research analyzes the nature of the WFD with its aims of reconfiguring national water politics in terms of policies, mechanisms and discourses by reflecting on the contradictions and controversies surrounding the directive. Methodologically, the research uses a critical analysis
\end{abstract}

Part of this article is based on Fausto Di Quarto's PhD dissertation ("Conflict \& Participation in the Governance of Nature: the case of the Seveso river basin, Milan", 2018), chapters 3, 4 and 5 .

\section{F. Di Quarto}

Department of Sociology and Social Research, University of Milano Bicocca, Milan, Italy

\section{A. Zinzani $(\bowtie)$}

Department of History and Cultures, Geography Unit, University of Bologna, Bologna, Italy

e-mail: andrea.zinzani4@unibo.it

\section{A. Zinzani}

Global Development Institute, University of Manchester, Manchester, UK and review of both theoretical and empirical academic literature and policy reports. The paper shows that political ecology, and the post-ecology perspective in particular, can be used to critically reflect on the WFD as a policy oriented towards technocratic governance and participatory arrangements that blur democratic political debate, marginalize conflicts and foster the politics of unsustainability.

Keywords Environmental governance $\cdot$ Water Framework Directive $\cdot$ Political ecology $\cdot$ Postecology

\section{Introduction}

Advanced modern societies are indeed post-growth societies-which is not to say that the logic of growth has been abandoned but that-in light of economic stagnation - the demands for further growth which are resolutely articulated by virtually all parts of society can be realised only for some, and at direct expense of others (Blühdorn, 2017).

Environmental issues have shaped the discourse and agenda of European institutions since the 1972 UN Conference on the Environment in Stockholm, formalizing the goal of balancing environmental protection and socio-economic development. Whereas the discourse at that time was influenced by the "limits 
to growth" vision, since the 1990s the concepts of sustainable development and sustainable economic growth have been the normative framework for environmental governance in the European Union. Over the last few decades and in keeping with this framework, European institutions have stressed the need to foster public participation and participatory processes in order to strengthen social and environmental policies. This vision has inspired various EU environmental policies and, in response to climate change and the global environmental crisis, it has been strengthened over the last few years through the formalization of the 2030 Agenda and the Sustainable Development Goals (SDGs). These initiatives have been strategically important in bringing about the global endorsement and promotion of the concept of Green Growth, with this concept recently emerging as the new hegemonic economic paradigm. Indeed, Green Growth legitimizes no-limits economic growth (based on endless capital accumulation) that is to be balanced by sustainable practices and "green" investments and technologies such as renewable and lowcarbon emission energies (Cavanagh \& Benjaminsen, 2017; Hickel \& Kallis, 2020).

As part of its environmental governance, the European Commission advanced the Water Framework Directive (WFD) in the 2000s with the aim of reconfiguring European water governance and the mission of establishing a new European water governance paradigm. The WFD stresses the importance of adopting river basin units for water governance, promoting participatory approaches and setting ecological parameters to protect waters, inspired by the principle of sustainability. However, a reflection on the political nature of the WFD suggests that the water paradigm is characterized by ambiguities and a controversial nature (Kaika, 2003). Over the last two decades, scholarship in critical geography and political ecology has recognized the importance of a critical approach to environmental governance and its policies to further our understanding of embedded power relations, political controversies, and depoliticization strategies and discourses (Adger et al., 2001; Bosselmann et al., 2008; Swyngedouw, 2011b; Cavanagh \& Benjaminsen, 2017). In particular, the perspective of post-ecology has highlighted the interplay between environmental governance policies and their numerous controversies in terms of encouraging and producing specific unsustainable socio-environmental relationships and futures.

In the political ecology framework and through the adoption of the post-ecology perspective in particular, this article analyzes the political nature of the WFD and its related aims and visions by critically reflecting on its main pillars, specifically its ideas of public participation and ecology. Data was collected and analyzed through a comparative policy and content analysis of academic literature and case study reports involving specific attention to discursive and political contexts and a critical reflection on WFD processes, practices and controversies. Our paper thus considers in particular how participatory governance mechanisms and ecologic targets have been produced by analyzing the discourses and ideologies on which they are built and related practices. This approach is important for addressing the causes of environmental degradation and embedded socio-ecological visions for sustainable futures in relation to the political nature of the WFD and its water governance strategies. It is highly useful, to this end, to understand who holds the power to impose specific socio-environmental visions on others.

Research in critical geography and political ecology stresses that democratic debates in environmental governance do not exist a priori, and participatory mechanisms are often adopted only when the environment requires restoration or decontamination, for instance in polluted areas or specific at-risk sites (Page \& Kaika, 2003; Swyngedouw, 2005; Blühdorn, 2014). Therefore, as long as these participatory mechanisms forestall any concrete political debate and deny conflicting claims by not failing to question the power imbalances that generated the environmental issue (such as degradation) in the first place, they operate merely as tools of restoration/conservation. In contrast, our perspective aims to show how these political processes and responsibilities are embedded in specific types of political-economic visions, in that every political project entails an environmental discourse and related socio-ecological scenario, as also argued by Heynen et al. (2006) and Swyngedouw (2011a) among others. Furthermore, we reflect on the nature of these processes to question whether the participatory arrangements championed by EU institutions and included in the WFD are actually better able to address environmental issues and enable a more effective handling of conflicts through the presumed 
democratization of environmental governance. The article opens with an overview of the European environmental governance framework, followed by a critical, political ecology-oriented examination of the post-ecology perspective aimed at questioning its nature and the concepts of sustainability and participation more specifically. It continues with a presentation of the WFD as a European policy and its main principles, politics and practices before discussing the main issues and controversies surrounding this directive in the last two sections.

\section{An overview of European environmental governance: sustainability, green growth and participation}

Different bodies of scholarship and theoretical perspectives have analyzed the notion of environmental governance and related institutional policies, mechanisms and practices over the last two decades, exploring their political vision and socio-economic and institutional rescaling processes. One troubling element of this model of governance is the controversial way it links up environmentally sustainable policies and principles of economic growth based on the concept of Ecological Modernisation (EM) as developed in the late 1980s. As argued by Hajer (1995, 1996), EM claims that economic and environmental objectives can be integrated within a framework of economic growth in which ecology is favorably combined in pursuing this goal. This idea of EM and the sustainable development framework have strengthened the vision of sustainability and inspired the Green Economy paradigm, a paradigm that has become hegemonic in European environmental governance and serves to support contemporary neoliberal policies. If we consider the political nature of European environmental governance, therefore, its main aim seems to be promoting economic development and eco-efficiency through "green growth" by framing environmental degradation and related issues as business opportunities for global capital (EEA, 2012; Knox-Hayes \& Hayes, 2014; Selin \& Van Deveer, 2015; De Maria \& Kothari, 2017). As part of these processes, a number of policies have targeted the point of convergence among environmental crises, economic interests and pro-growth opportunities. The sustainability vision has been further advanced and reinforced since 2015 with the formalization of the 2030 Agenda and the Sustainable Development Goals (SDGs), developed as global guidelines for governments and policy-makers to facilitate national economic and environmental processes in transitioning towards green growth (Brown et al., 2014).

Participatory mechanisms have become central to this policy framework since the 2000s in an effort to raise awareness about environmental issues and highlight the need for public engagement in decisionmaking processes (Parkins \& Mitchell, 2005; Korf, 2010; Carvalho et al., 2016). For the EU, widening participation represents a strategic goal that would enable member states to achieve sustainable development mainly through good governance, social inclusion and participatory processes. Indeed, in 2003 Directive 2003/35/EC stated that public involvement in decision-making is vital in terms of objectives, plans and programmes for justice (European Commission, 2015). ${ }^{1}$ In recent European environmental policies, participatory planning was promoted and formally adopted in the Water Framework Directive (2000), Flood Directive (2007) and Air Quality Directive (2008) (Newig \& Koontz, 2013). The main assumption underlying this policy trend is that participation, if properly enacted, entails more democratic decision-making processes, greater social cohesion, improved policy quality and effectiveness, and even conflict resolution, as stated by Scolobig et al. (2016). Over the last decade, therefore, EU environmental governance has made an impressive formal effort to become an international frontrunner in promoting participation. And yet some geography and political ecology scholars engaged in critically analyzing and deconstructing policies and discourses and reflecting on their political and conflicting dimensions have pointed out that sustainability policies and participatory mechanisms are actually controversial.

\section{A critical perspective on European environmental governance: political ecology and post-ecology in dialogue}

European institutions have been dealing with environmental issues in the context of socio-

\footnotetext{
${ }^{1}$ https://eur-lex.europa.eu/legal-content/EN/TXT/?uri= CELEX\%3A32003L0035.
} 
environmental relations since the 1980s. To date, if we consider the global environmental and climate crisis, it seems that efforts to reduce or reverse unsustainable paths have not been particularly effective in reaching their goals. Indeed, despite research, policy-making and economic investment to address environmental issues, there is no evidence that contemporary neoliberal democracies and their related governance produce more sustainable outcomes (Bosselmann et al., 2008). In fact, while on the one hand a move towards sustainable development (SD) might impact and benefit economic growth, on the other hand it seems that this type of development does not imply effective steps towards sustainability. Marxist thought was among the first to point out the contradictory relationship between capitalism and environmental sustainability and scholars have argued that capitalism necessarily undermines the conditions of production-soil, water, energy and so forth-to sustain capital's endless accumulation (Marx, 2008 [1867]; O'Connor, 1998; Foster, 1999). Nevertheless, despite the tension between the nature of capitalism and environmental protection, since the beginning of the 1990s the paradigm of sustainability has asserted that the current socio-ecological configuration is "no longer contradictory when brought together under the notion of sustainable development", as stated by Baeten (2000). The idea behind this framework is that, given rational and efficient ecological modernisation, capitalism and environmental protection can be combined through 'green eco-friendly' economy and the sustainable use and consumption of natural resources (Gouldson \& Murphy, 1997; Pellizzoni, 2001).

However, evidence from around the globe shows that this approach is problematic and questionable, in particular if we consider the current global environmental and climate crisis embedded in the conceptualization of the Anthropocene with its increasingly unsustainable socio-ecological conditions potentially portending a catastrophic future for human and nonhuman nature alike (Mikkelson et al., 2007; Motesharrei et al., 2014; Hallmann et al., 2017). Political ecology scholars suggest that both ecological claims and green arguments have been somehow hijacked by sustainable development discourse. The radical demands for different socio-environmental futures that have arisen since the 1970s, they argue, were slowly co-opted by the dominant discourses of the SD narrative, in part by incorporating activists' calls for eco-friendly energy production, 'green' food, and grassroots participation to enhance democracy (Blühdorn \& Welsh, 2007; Læssøe, 2007). Swyngedouw (2011a, b) adds that the sustainability argument gutted the politics of the possible-the radical assertion of alternative socio-environmental arrangements in the future-and silenced the contestation and conflicts that are constitutive of our socio-environmental orders by marginalizing critical voices. Indeed, SD is critiqued on the grounds that it tends to prioritize short-term economics over long-term sustainability: according to this critical view, the nature of neoliberal democracies favors short-term green arrangements over long-term responsibility.

As outlined in the previous section, since the 2000s the EU has touted participatory processes as a key mechanism for sustainability, a means of co-producing decisions that are more democratic and better adapted to local conditions (Page \& Kaika, 2003; Antunes et al., 2009; Jager et al., 2016). On the formal level, these arrangements enhance democratic principles such as transparency and accountability; they are intended to generate more effective synergies between institutional and social actors and specifically to produce, rhetorically, shared and naturalized agreements and visions. However, these participatory arrangements produced and coordinated according to an institutionalized perspective have been called into question by various scholars. When managed with an eye to building consensus, critics argue, these arrangements represent a symptomatic strategy of institutional subjugation through co-optation that deny the political dimension (Blühdorn, 2014; Dikeç, 2005; Holifield \& Schuelke, 2015; Swyngedouw, 2005). The core of the emancipatory project championed by political ecologists, and critical scholars more generally, is instead the struggle for democracy. This struggle represents the key, conflictual process for achieving real socio-ecological sustainability, understood as a strategy for fostering a more equitable distribution of social power and more inclusive way of producing the environment. Moreover, this process of contestation is essential for repoliticizing top-down institutional participatory mechanisms and transcending these practices to enable an effective and wideranging debate about the democratization of decisionmaking dynamics, environmental politics and environmental futures. 
The concept of "post-politics" was coined to describe the current neoliberal political framework in which techno-managerial planning and intervention, experts management and bio-political administration replace democratic debate and marginalize dissenting voices (Wilson \& Swyngedouw, 2014). Critical scholars argue that post-politics governance is actually aimed at inhibiting internal conflict among actors and reducing the space for dissent (Richardson, 2015). Analyses of contemporary eco-political discourse and practices that are critical of the postpolitics trend find that a key issue of this post-political condition is that communities are deprived of their political power (Blühdorn, 2011, 2013; Swyngedouw, 2005, 2011a, b). In particular, Swyngedouw (2005) defines these mechanisms as 'Janus- Faced' in that these new modes of governance are rarely based on codified and transparent rules, tend to be highly selective of which actors are allowed to participate as stakeholders, and are ill-defined in terms of the nature of the representation they offer and the legitimacy they generate. Swyngedouw (2005) further argues that the political objectives and priorities of participatory mechanisms often remain ambiguous, thereby dispersing political responsibility and obscuring chains of accountability. Blühdorn $(2011,2013,2014)$ has recently contributed to this discussion by, with an eco-political analysis of post-politics, arguing that the characteristics of these flexible structures of governance, such as their contradictory, Janus-faced features, render them exceptionally attractive to the postpolitical (and post-democratic) condition and suited to the politics of unsustainability. Critical perspectives have framed this type of politics as the practice of managing the unpleasant implications of ecological change for as long as possible through a political rationale that prioritizes contemporary interests at the expense of those of future generations (Ibid.). According to this view, neoliberal democracy becomes a tool for governing unsustainability, i.e. the lifestyles choices and value-preferences created by modern democratic-mass consumption societies with their socially exclusive and ecologically ruinous logics. These governance approaches function to stabilize and legitimize lifestyles that exacerbate social injustice and environmental exploitation through a mechanism of 'simulative politics', as Blühdorn points out (2007). They represent a powerful mechanism for reducing opposition and social conflict, generating a form of democratic legitimacy for policies that allow certain segments of society to continue practicing their nonnegotiable norms and lifestyles while at the same time imposing significant restrictions for other segments. Governance approaches focused on stakeholder participation are a response to "a strong societal demand for arenas and practices of simulative politics" (Blühdorn, 2013). In this context, Blühdorn argues, democracy is actually maintained for ecological purposes, albeit in a perverted manner; democracy is transformed into the most important mechanism for the 'politics of unsustainability' (2011) characterizing our current post-ecology era (1997, 2007). Postecology is thus basically framed around the questions "How do neoliberal consumer democracies try and manage to sustain what is known to be unsustainable? How can we manage, nationally and internationally, the socio-environmental consequences of sustaining the unsustainable?" (2009). Both Bluhdorn and Swyngedouw contribute to this theoretical debate by outlining different visions of the political dilemma as a strategy for tackling socio-environmental issues. While Swyngedouw focuses to a large extent on the politically axiomatic concept of equality and the way it is constantly being undermined, Blühdorn argues that the strategic move would be to recognize today's cultural shift (changing notions of subjectivity) and related lifestyles as socially and ecologically responsible for the current situation. In this context, we argue that, moving beyond political ecology's simplistic democracy vs. technocracy binary, Bluhdorn's insights and his post-ecology perspective can be used to generate a more effective theorization of current socio-environmental relations in neoliberal democracies by analyzing EU environmental post-democratic governance and specifically the WFD. This analytical framework thus enables us to conduct an initial investigation of the WFD as a policy tool for stabilizing and legitimizing contemporary socio-environmental relations by managing the unpleasant implications of the environmental crisis for as long as possible through illusory participation and social inclusion, thereby fueling the politics of unsustainability. 


\section{The Water Framework Directive and its milestones}

The European Water Framework Directive (WFD) was developed at the beginning of the 2000s with the aim of reconfiguring European water governance on multiple scales and, ultimately, becoming the prevailing paradigm of European water governance. It represents one of the most significant and prominent examples of European environmental governance: the WFD is portrayed as one of the first and most ambitious pieces of environmental legislation implemented in Europe so far, despite its controversial nature (Jager et al., 2016; Kaika, 2003; Page \& Kaika, 2003). Indeed, if we reflect on the nature of the WFD we find that it incorporates diverse and heterogeneous contradictions, ranging from spatial and rescaling processes, governance mechanisms and participation, to visions and perspectives on environmental conservation, socio-ecological futures and the economic dimension of water as a resource (Carter, 2007). Moreover, the WFD's vision and guidelines embody both the idea of water as a collective resource that should be governed in a participatory, inclusive and horizontal manner, and the conflicting vision of water as a commodity. These controversial elements can be examined in relation to the directive's three main milestones.

Historically, the WFD follows the evolution in water legislation which took place in the EU starting from the 'drinking water' laws of 1975 and 1991 'emission levels legislation'. It represents the first common frame of reference for water legislation in the EU and, since it was declared legally binding, over the last two decades it has brought about various transformations and had a significant impact on European states. As recently stated by Carvalho et al. (2019) in their evaluation of WFD implementation procedures, although the directive is meant to play a key role in achieving an effective sustainable water governance future by 2027 , it is still characterized by a wide range of policy, institutional and technical issues. However, this analysis by Carvalho et al. (2019) overlooks the WFD's political controversies and the global, transcalar debate about the weaknesses and contradictions of environmental policy-making over the last few years, in particular in relation to the gravity of the global environmental crisis. In terms of its structure, principles and main objectives, the directive sets three milestones of water governance to be progressively implemented in national water legislation:

(a) the reconfiguration of water governance from administrative units to integrated river basins;

(b) the formalization of ecological and chemical parameters and emission controls to protect water quality;

(c) the promotion of public participation-information, consultation or involvement.

\section{River basin organizations}

The first milestone defines a new territorial unit for water governance based on a different scale of intervention: the river basin as a hydrologic territorial unit. In institutional terms, this principle involves establishing a series of river basin governance authorities and related plans. In the WFD, the point of this principle and its implementation aimed at redrawing the boundaries of water authorities of European states from administrative to hydrologic principles. As Boeuf and Fritsch (2016) have stated, the WFD planning process-consisting of eight steps $^{2}$ - is a complex institutional reconfiguration process that implies a significant increase in the number of actors involved in water governance policies, jurisdiction and responsibilities. Such reorganization conceals another outcome, however, namely the depoliticization of the heterogeneous and controversial nature of water governance; on a global scale in particular, over the last twenty years this institutional process have generated opportunities for new private/public partnerships and, in many cases, for the private control of water and related commodification, as also highlighted by Melo Zurita et al. (2015). Moreover, this heterogeneous space of institutions, agencies, private-public and private actors all involved in water governance is an example of the kind of fragmented power that has resulted from the politics of state devolution pursued

\footnotetext{
2 These are: assessment of water status, characterization of physical and societal pressures on water bodies, designation of artificial and heavily modified water bodies, determination of atrisk water bodies, revision of an existing River Basin Management Plan, adoption of a Programme of Measures to outline concrete actions, implementation of those two documents, monitoring, and review. This sequence of activities has to be repeated every 6 years.
} 
in Europe over the past two decades (Perreault, 2014; Smith et al., 2014).

Indeed, critical geography and political ecology research shows that river basin units are expansive arenas in which complex interactions among institutions, social groups and the environment produce different and controversial examples of water governance. Molle et al. (2009) has contributed significantly to this view by denouncing the depoliticization entailed in this shift towards river basin governance and the importance of critically reflecting on power discourses as well as both the convergent interests of stakeholders and their asymmetrical degrees of influence. Other scholars have highlighted the main issues plaguing WFD river basin units, showing that water governance rescaled to the local level and river basin fetishism are not necessarily the most appropriate scale of governance (Norman \& Bakker, 2009; Harris \& Alatout, 2010; Zinzani \& Bichsel, 2018). Research has found that river basin governance and participatory mechanisms have been used to legitimize specific institutional strategies while depoliticizing water access and distribution issues (Swyngedouw 2011a, b). Therefore, such critics suggest, the idea of river basin governance and related plans and councils were promoted by the European Union as a top-down "mantra" of implementation that failed to consider either the diverse and heterogeneous environmental and socio-political complexities of European river basins, or the needs and claims of their stakeholders (De Loe \& Patterson, 2017).

\section{Ecological targets}

The second milestone of the WFD represents a controversial transformation process in that it formally calls for specific attention to the principle of sustainability and ecological standards. Although the sustainability principle had already been playing a key role in EU environmental governance for decades, the WFD represented the very first legally binding document to enshrine surface and groundwater protection, a combined approach of emissions limits and standards for water quality and, since 2015 , a 'good status' target (art.4).

Whereas environmental protection was considered only marginally until a few decades ago, today it plays a key role in debates on water governance on diverse scales. The directive establishes that water is not a commercial resource; at the same time, it stresses the importance of ensuring water quality (preamble 11), reducing hazardous substances (22) and, for the first time in European environmental legislation, the precautionary principle (4). Indeed, the WFD stated that both good surface water status and good groundwater status were key objectives to be achieved by 2015 . However, neither the WFD in general nor this milestone specifically consider or reflect on the roots of pollution issues, in particular with regards to water; they likewise fail to address the ecological repercussions of the increase in hydraulic infrastructure construction over the last few decades in terms of potential environmental degradation (Valinia et al., 2012). Furthermore, the WFD promotes controversial market-based initiatives to deal with water pollution and degradation.

Indeed, EU mechanisms for resolving water quality issues seem to clash with the opening of the directive and particularly its framing of water as a noncommercial good. The text of the directive holds up the "polluters pay principle" as the most effective mechanism for protecting water resources by pricing and commodifying them (preambles 11 and 38; art.9). This statement, illustrative of the deeply controversial nature of the WFD, triggered a significant debate during the directive's formalization about the powerful role of private and public-private entities as new actors in global water governance (Kaika, 2003). It is here that we see the controversial status of water in the WFD, conceptualization at one point as a common public resource and at other points as a commodified good in the global market. Indeed, this point of contradiction is central to the directive and it is worth noting that the conceptualization of water as a common public resource, and especially the discursive dissemination of this framing, was used strategically to compensate for the parallel introduction of marketoriented mechanisms and the enlarged role granted to private companies, and to build consensus around ideas of social inclusion and participation.

Public participation

The third milestone of the WFD formalizes public participation in water governance. The preamble and article 14 underline the importance of citizen involvement through information-sharing and consultation and, especially, through involvement in river basin 
organizations; indeed, such active collaboration is considered strategic for successful implementation. In particular, three years after the formalization of the WFD, Directive 2003/35/EC (Public Participation in Respect of the Drawing up of Certain Plans and Programmes Relating to the Environment and Amending with Regard to Public Participation) strengthened and highlighted the importance of public participation channels to involve civil society (NGOs, organizations and individual citizens) in environmental and water governance as part of the Arhus Convention. As argued by Boeuf and Fritsch (2016), public engagement activities involve three components: information-sharing, consultation and active involvement. Information-sharing requirements mainly include the obligation to carry out status and risk assessments and to make background information and maps publicly available. In terms of consultation, member states have to organize three rounds of public comment during the preparation of River Basin Management Plan. Active involvement refers to a more intense mode of participation that may include planning at the level of small groups.

In particular, Article 2 stresses the importance of public engagement for enacting the legislation and tasks member states with identifying the 'public' that is entitled to participate. This requirement makes the issue of entitlement problematic in terms of what kind of participation is envisioned and what actors, interests, power and visions are involved. Indeed, there is a tendency to suppress real political discussion in favor of promoting participation; such substitution has represented a strategic move in diverse decisionmaking processes in European environmental governance. Whereas the WFD states that 'active public participation' in river basin planning is essential, it does not guarantee a fully inclusive participatory process or consider the implications of power relations in shaping actors' roles in this process. Therefore, as Kaika (2003) also points out, neither practices of participation nor the roles of different political actors are institutionally defined by the directive. According to WFD principles, participation mechanisms include the public making suggestions to authorities and authorities having the (non-binding) task of informing the public; the decision-making process must entail participation in order to render final decisions more legitimate. Therefore, participatory mechanisms serve as a strategy for protecting the process from the conflict and disagreement that can arise around water governance. This process of public involvement aims to achieve consensus-based deliberation by taking into account diverse perspectives (although not all of them, as the thornier or more conflicting ones are disregarded) rather than dealing with power struggles. Therefore, by linking WFD mechanisms for involving the public to the perspective and logics of postecology, participatory processes seem to be brought into this socio-environmental order, an order that reproduces its own mechanisms, strategies and visions by marginalizing political debate and potential disagreement, and rejecting any deeper consideration of long term socio-environmental futures that could overturn today's concepts of sustainability and green growth.

\section{The WFD in relation to the post-ecology perspective: implementing the politics of unsustainability}

The WFD was formalized in 2000, and since $2003 \mathrm{EU}$ countries have been expected to reorganize their national water legislation to implement it. Although the directive is legally binding, there are two important elements that have hampered and complicated its implementation. Firstly, despite the document's status as a binding legal act, the fact that it is a directive means that it represents more a requirement to achieve a specific result than a real and effective 'regulation'. Secondly, as Kaika (2003) has also argued, the WFD is the product of negotiations and political processes carried out over a long period of time and has thus been interpreted and reconfigured differently by individual member states. Considering these premises, it is not surprising that most of the objectives of the WFD have yet to be achieved fifteen years later and that, as recently stated by Carvalho et al. (2019), a heterogeneous range of issues continues to plague its implementation.

As presented and discussed in the previous section, the WFD is structured around the principle that riverbasin units facilitate governance as well as the involvement and participation of water users at the local level, the level at which conflicting water use and distribution are rooted. European Union institutions and national governments alike have promoted this principle of participation as the most natural way of 
managing water resources and the best practice for such management without granting in-depth consideration to either existing water politics and socioenvironmental arrangements or the implications of the WFD's spatial and political reconfiguration process. Furthermore, this governance approach seems to encourage institutional and management fragmentation rather than interconnection, and, as Del Moral and Do Ó (2014) also note, it does not necessarily facilitate a bottom-up, integrated and multi-scalar process.

Focusing on ecological quality in relation to WFD objectives, in 2015 the Commission released its latest report (following those of 2007, 2009 and 2012) featuring what appear to be critical findings: according to the report, by 2015 all the water bodies in the EU were to have achieved 'good ecological status'. This target remains a challenge for the future, however, as $47 \%$ of surface waters had yet to reach a 'good' status and the number of 'good' bodies of water increased by only $10 \%$ between 2009 and $2015 .{ }^{3}$ Indeed, the notion of ecological quality, which has itself been contested by a variety of stakeholders on multiple levels, has been interpreted differently on the basis of distinct approaches; furthermore, the EU has not provided a clear definition of good ecological status or water types in its parameters. One of the obstacles to meeting the WFD's ambitious targets is a lack of clarity as to implementation procedures, as Voulvoulis et al. (2017) have also observed. The 2015 report (EC 2015) outlines the gap between the goal and the actual situation by identifying various issues as the reason for non-attainment. Pollution mainly stems from agricultural, industrial and household sources, and the preliminary directives related to these sources (Nitrate, Urban Waste, Industrial Emissions) are seen as challenging to implement due to the financial and planning requirements of infrastructure and treatment systems (EC 2015). Moreover, there is no general agreement among states over chemical pollution or general measures, and expected outcomes remain vague and controversial. Even more controversial in terms of solutions for resolving water quality issues is the WFD's own deep-seated ambiguity, oscillating between the principle of water as a common public resource and water as a commodity.

\footnotetext{
3 https://ec.europa.eu/environment/water/waterframework/pdf/ 4th_report/CSWD\%20Report\%20on\%20WFD\%20PoMs.pdf.
}

Over the last several years, the WFD has progressively pushed environmental governance in EU countries towards participatory processes. For instance, in discussing the evidence from $13 \mathrm{EU}$ states in a comparative approach, Jager et al. (2016) show that participatory processes prove to be varyingly inclusive, characterized by different levels of awareness, inclusion and power asymmetries that have shaped final decisions in divergent ways. However, there is apparently no evidence of a direct relationship between WFD participatory processes and environmental impact in terms of socio-environmental benefits. Indeed, the data show that stakeholders were involved in only $20 \%$ of WFD decision-making and that these processes often failed to meet the expectations and demands of the different actors and stakeholders involved in the processes in terms of effective negotiation (Voulvoulis et al., 2017). This finding conflicts deeply with the rhetoric of EU environmental governance and the WFD's own marked emphasis on the importance of participation and democratic mechanisms in decision-making and, at the same time, the so-called "social" dimension of sustainable development.

Moreover, we stress that the WFD lacks clear and effective guidelines about stakeholders' right to participate and fails to specify when and according to what logics public participation ought to be adopted and cultivated. It is worth noting that public participation is not an explicit aim of the WFD; rather, public involvement is rhetorically encouraged only in the phase of implementation and not as a part of long-term strategy. On the basis of our analysis, we would argue that participatory arrangements should first and foremost raise awareness about water issues, especially by enhancing horizontal relationships between institutional and social actors in addressing multi-layered local issues. Secondly, participatory processes could facilitate information-sharing and the cultivation of common interests in relation to river-related issues, including on-site activities to maintain and restore water bodies. However, based on a review of the literature and data collected in case study reports, we suggest that local civil society stakeholders such as the members of local communities are often excluded from decision-making processes, especially those focused on local issues. Furthermore, even when participatory processes have been organized-often with severe power asymmetries-they neither imply 
shared interests nor strengthen the motivations of citizens. Rather than balancing or reducing uneven power relations, therefore, WFD participatory mechanisms actually appear to exacerbate power and decision-making asymmetries between stakeholders in order to curb democratic debate and potentially neutralize dissent about the WFD, its vision, politics and practices. If we consider the WFD in relation to the framework of environmental governance, EU legislation-even if it is legally binding - seems to leave little room for moving towards broader environmental policies that would address issues in an integrated manner. What is lacking is the kind of holistic view on water and related ecological issues that would potentially generate regulations and legally binding documents in which governance mechanisms are co-promoted by all the local actors, especially those who are directly affected. As discussed above, water governance issues must be managed systemically so that other sectors, such as land planning, can be integrated into new programs and novel scenarios. Moreover, the WFD needs to establish a multidimensional definition of water accompanied by instruments and initiatives that reflect multiple values and entail equitable participation as a strategy for enabling the legitimate reconciliation of such divergent values in nationally-appropriate contexts.

By considering the politics of the WFD in the framework of political ecology and specifically in relation to the post-ecology perspective, we find that the arenas of environmental governance and related arrangements leave little room for structural transformation in the direction of truly sustainable environments (Blühdorn, 2013). Indeed, the WFD was designed by international experts, policy makers and technicians according to a top-down and technocratic approach that somehow sidelines blocks any open, inclusive and democratic debate about its milestones, practices and outcomes. Beyond the WFD's rhetorical discourse about the aim of sustainability and the current status of transcalar water governance in EU member states, there is a marked lack of discussion about the directive's socio-environmental vision and related futures. As stated by Blühdorn (2017), the merely simulative politics of inclusion characterizing the WFD operates as a collective societal practice for managing the implications of its commitment to sustain the unsustainable. Indeed, the WFD and related governance processes are situated in the broader framework of sustainable economic growth, the framework that constitutes the dominant paradigm endorsed by national and international actors and embedded in European policies. European environmental governance has fully adopted a strategy of coopting any radical socio-environmental alternatives, endorsing the paradigm of 'ecological modernisation' and, later, the idea of 'green growth', as a way to continue pursuing environmental unsustainability (Blühdorn \& Welsh, 2007). As our analysis of the WFD shows, this strategy is deployed to simulate serious concern for the environment, relying on participation, green technology and economic growth in the context of neo-liberal economic arrangements that support resource commodification. At the same time, however, it serves to maintain the socioeconomic paradigm unchanged. Over the last two decades, sustainable development discourse has gained ground as a way of reconciling economic growth and sustainability, overlooking power imbalances in local areas: indeed, these forms of inequality and related marginalization have very often been concealed behind technical discourses. Therefore, reflecting on the politics of the WFD enables us to highlight key controversies such as existing power imbalances in water governance, especially in the areas of democratic debate and decision-making, as well as in access to the resource of water. In so doing, we critically question the 'taken-for-granted' concepts that have produced and sustained the politics of unsustainability in this area. Indeed, through the perspective of post-ecology, we argue that environmental governance initiatives based on current EU legislation such as the WFD reflect a lack of a systemic approach to socio-environmental issues, a lack that also legitimizes contemporary configurations of unsustainability and the resilience of unsustainable governance.

\section{Conclusion}

This article offers a critical reflection on European environmental governance and the nature of the WFD, its policies, pillars and discourses. By adopting a political ecology approach and the post-ecology analytical perspective, we have explored how multiscalar water governance in the EU has produced a complex framework of controversial and uneven 
socio-environmental conditions on different geographical scales over the last several decades: complex institutional change, vague water and ecological targets, and questionable, depoliticized participatory mechanisms.

Indeed, the implementation politics of the WFD from 2000 onward have resulted in a fragmentation of governance activities and a lack of integrated planning policies, thus generating asymmetries between European laws on water and the management of land and other resources. Water and land planning issues are not tackled as a common and inter-related matter: the WFD promotes and suggests limits and conditions on ecological targets, but it neither sanctions non-compliance nor interrogates the roots of environmental degradation, thus basically leaving member states free to deal with environmental issues nationally. Public participation could work as a strategic political mechanism in focusing renewed attention on water and environmental contexts, especially by generating more horizontal synergies among institutional actors in addressing multi-layered local issues and serving as a catalyst to stimulate interest, awareness and political action. Even when participatory processes are presented as inclusive and balanced in terms of bargaining power, however, they tend to depoliticize and naturalize diverging interests and claims. In particular, institutionalized and top-down participatory processes in the WFD have reduced the scope of democratic debate and the potential influence of participants' claims on water governance decision-making processes.

Therefore, we argue that, given the fragmented and depoliticized approaches and practices characterizing environmental governance and specifically the WFD, these strategies are doomed to fail. Complex socioenvironmental relationships must instead be governed through a holistic and genuinely participatory perspective characterized by just and democratic debate. It is indeed a political choice to recognize and 'connect the dots' between water governance, planning policies, and environmental issues, and to reflect on the limits of economic growth and related issues. Bottomup socio-environmental politics could provide a significant contribution to instituting sustainable, inclusive and just environmental governance. Specifically, as political ecology scholars and the postecology perspective have shown, foregrounding limits to growth represents a strategic step forward in effectively resolving today's environmental conundrum. Indeed, thanks to Bluhdorn's insights we can argue that water governance's participatory and bottom-up strategies are ineffective and fail to benefit socio-environmental relations without a comprehensive recognition of structural limits to growth and a reconfiguring of policies and discourses. To date, the WFD's current policies and participatory arrangements seem to have worked as an instrument and narrative device for legitimizing green and sustainable policies and practices while at the same time fostering the politics of unsustainability. Re-politicizing these processes would require active debate in the democratic, political, public sphere about possible alternatives to the existing order. Today's socioenvironmental justice claims could be considered a fruitful terrain for repoliticizing environmental governance and rendering it more democratic in order to generate new societal imaginaries and new socioecological relations.

Author contributions Fausto Di Quarto designed Sects. 2 and 3 while Andrea Zinzani wrote Sects. 1 and 4. Sections 5 and 6 were designed by both authors.

Funding Open access funding provided by Alma Mater Studiorum - Università di Bologna within the CRUI-CARE Agreement.. Research was funded through Fausto Di Quarto's Ph.D fellowship (2014-2017) of the Ph.D. Urbeur "Sociology and Social Research", University of Milano Bicocca (Italy).

\section{Declaration}

Conflict of interest The authors declare that they have no conflict of interest.

Open Access This article is licensed under a Creative Commons Attribution 4.0 International License, which permits use, sharing, adaptation, distribution and reproduction in any medium or format, as long as you give appropriate credit to the original author(s) and the source, provide a link to the Creative Commons licence, and indicate if changes were made. The images or other third party material in this article are included in the article's Creative Commons licence, unless indicated otherwise in a credit line to the material. If material is not included in the article's Creative Commons licence and your intended use is not permitted by statutory regulation or exceeds the permitted use, you will need to obtain permission directly from the copyright holder. To view a copy of this licence, visit http://creativecommons.org/licenses/by/4.0/. 


\section{References}

Adger, W. N., Benjaminsen, T. A., Brown, K., \& Svarstad, H. (2001). Advancing a political ecology of global environmental discourses. Development and Change, 32(4), 681-715.

Antunes, P., Kallis, G., Videira, N., \& Santos, R. (2009). Participation and evaluation for sustainable river basin governance. Ecological Economics, 68(4), 931-939.

Baeten, G. (2000). The tragedy of the highway: Empowerment, disempowerment and the politics of sustainability discourses and practices. European Planning Studies, 8(1), $69-86$.

Blühdorn, I. (2011). The politics of unsustainability: COP15, post-ecologism, and the ecological paradox. Organization \& Environment, 24(1), 34-53.

Blühdorn, I. (2013). The governance of unsustainability: Ecology and democracy after the post-democratic turn. Environmental Politics, 22(1), 16-36.

Blühdorn, I. (2014). Post-ecologist governmentality: Postdemocracy, post-politics and the politics of unsustainability. In E. Swyngedouw \& J. Wilson (Eds.), The post-political and its discontents: Spaces of depoliticisation, spectres of radical politics (pp. 146-166). Edinburgh University Press.

Blühdorn, I. (2017). Post-capitalism, post-growth, post-consumerism? Eco-political hopes beyond sustainability. Global Discourse, 7(1), 42-61.

Blühdorn, I., \& Welsh, I. (2007). Eco-politics beyond the paradigm of sustainability: A conceptual framework and research agenda. Environmental Politics, 16(2), 185-205. https://doi.org/10.1080/09644010701211650.

Boeuf, B., \& Fritsch, O. (2016). Studying the implementation of the Water Framework Directive in Europe: A meta-analysis of 89 journal articles. Ecology and Society, 21(2), $1-19$.

Bosselmann, K., Engel, R., \& Taylor, P. (2008). Governance for sustainability. Issues, challenges, successes. Corporate governance. IUCN.

Brown, E., Cloke, J., Gent, D., Johnson, P. H., \& Hill, C. (2014). Green growth or ecological commodification: debating the green economy in the global South. Geografiska Annaler: Series B, Human Geography, 96(3), 245-259.

Carter, J. G. (2007). Spatial planning, water and the Water Framework Directive: Insights from theory and practice. Geographical Journal, 173(4), 330-342. https://doi.org/ 10.1111/j.1475-4959.2007.00257.x.

Carvalho, A., Pinto-Coelho, Z., \& Seixas, E. (2016). Listening to the public-Enacting power: Citizen access, standing and influence in public participation discourses. Journal of Environmental Policy \& Planning, 21(5), 1-19. https://doi. org/10.1080/1523908X.2016.1149772.

Carvalho, L., Mackay, E. B., Cardoso, A. C., Baattrup-Pedersen, A., Birk, S., Blackstock, K. L., et al. (2019). Protecting and restoring Europe's waters: An analysis of the future development needs of the water framework directive. Science of the Total Environment, 658, 1228-1238.

Cavanagh, C., \& Benjaminsen, T. A. (2017). Political ecology, variegated green economies and the foreclosure of alternative sustainabilities. Journal of Political Ecology, 24(1), 200-216.

De Loe, R. C., \& Patterson, J. J. (2017). Rethinking water governance: Moving beyond water-centric perspectives in a connected and changing world. Natural Resources Journal, 57(1), 75-100.

De Maria, F., \& Kothari, A. (2017). The post-development dictionary agenda: Path to the pluriverse. Third World Quarterly, 38(12), 2588-2599.

Del Moral, L., \& Do Ó, A. (2014). Water governance and scalar politics across multiple-boundary river basins: States, catchments and regional powers in the Iberian Peninsula. Water International, 39(3), 333-347.

Dikeç, M. (2005). Space, politics and the political. Environment and Planning D: Society and Space, 23(2), 171-188.

European Commission. (2015). Assessment of member states' progress in the implementation of programmes of measures during the first planning cycle of the Water Framework Directive member state report: Italy (IT). (March), pp. 1-42.

European Environmental Agency. (2012). Climate change, impacts and vulnerability in Europe 2012. EEA Report 12.

Foster, J. B. (1999). Marx' S theory of metabolic rift: Classical foundations for environmental sociology. American Journal of Sociology, 105(2), 366-405.

Gouldson, A., \& Murphy, J. (1997). Ecological modernisation: Restructuring industrial economies. In M. Jacobs (Ed.), Greening the millennium? The new politics of the environment. Blackwell.

Hajer, M. A. (1995). The politics of environmental discourse: Ecological modernization and the policy process. Oxford University Press.

Hajer, M. A. (1996). Ecological modernisation as cultural politics. In S. Lash, B. Szerszynski, \& B. Wynne (Eds.), Risk, environment \& modernity. Towards a new ecology ( $\mathrm{pp}$. 246-268). Sage.

Hallmann, C. A., et al. (2017). More than 75 percent decline over 27 years in total flying insect biomass in protected areas. PLoS ONE, 12(10),

Harris, L. M., \& Alatout, M. (2010). Negotiating hydro-scales, forging states: Comparison of the Upper Tigris/Euphrates and Jordan River Basins. Political Geography, 29, 148-156.

Heynen, N., Kaika, M., \& Swyngedouw, E. (2006). In the nature of cities: Urban political ecology and the politics of urban metabolism. Routledge.

Hickel, J., \& Kallis, G. (2020). Is green growth possible? New Political Economy, 25(4), 432-444.

Holifield, R., \& Schuelke, N. (2015). The place and time of the political in urban political ecology: Contested imaginations of a river's future. Annals of the Association of American Geographers, 105(2), 294-303.

Jager, N. W., et al. (2016). Transforming European Water Governance? Participation and river basin management under the EU Water Framework Directive in 13 member states. Water, 8(156), 1-22. https://doi.org/10.3390/ w8040156.

Kaika, M. (2003). The Water Framework Directive: A new directive for a changing social, political and economic European frame work. European Planning Studies, 11(3), 299-316. https://doi.org/10.1080/0965431032000070802. 
Knox-Hayes, J., \& Hayes, J. (2014). Technocratic norms, political culture and climate change governance. Geografiska Annaler: Series B, Human Geography, 96(3), 261-276.

Korf, B. (2010). The geography of participation. Third World Quarterly, 31(5), 709-720.

Læssøe, J. (2007). Participation and sustainable development: The post-ecologist transformation of citizen involvement in Denmark. Environmental Politics, 16(2), 231-250. https://doi.org/10.1080/09644010701211726.

Marx, K. (2008 [1867]). Capital a critique of political economy volume I book one: The process of production of capital first. I. https://www.marxists.org/archive/marx/works/ 1867-c1/ch15.htm\#S10.

Melo Zurita, M. D. L., Thomsen, D. C., Smith, T. F., Lyth, A., Preston, B. L., \& Baum, S. (2015). Reframing water: Contesting $\mathrm{H} 2 \mathrm{O}$ within the European Union. Geoforum, 65, 170-178. https://doi.org/10.1016/j.geoforum.2015.07. 022.

Mikkelson, G. M., Gonzalez, A., \& Peterson, G. D. (2007). Economic inequality predicts biodiversity loss. PLOS ONE, 2(5),

Molle, F. (2009). Water, politics and river basin governance: Repoliticizing approaches to river basin management. Water International, 34(1), 62-70.

Molle, F., Mollinga, P., \& Wester, P. (2009). Hydraulic bureaucracies and the hydraulic mission: Flows of water, flows of power. Water Alternatives, 2(3), 328-349.

Motesharrei, S., Rivas, J., \& Kalnay, E. (2014). Human and nature dynamics (HANDY): Modeling inequality and use of resources in the collapse or sustainability of societies. Ecological Economics, 101, 90-102.

Newig, J., \& Koontz, T. M. (2013). Multi-level governance, policy implementation and participation: the EU's mandated participatory planning approach to implementing environmental policy. Journal of European Public Policy, 21(2), 248-267. https://doi.org/10.1080/13501763.2013. 834070 .

Norman, E., \& Bakker, K. (2009). Transgressing scale: Water governance across the Canada-U.S. Borderland. Annals of the Association of Americal Geographers, 99(1), 99-117.

O'Connor, J. (1998). Natural causes: Essays in ecological Marxism. Guilford.

Page, B., \& Kaika, M. (2003). The EU Water Framework Directive: Part 2. Policy innovation and the shifting choreography of governance. European Environment, 13(6), 328-343. https://doi.org/10.1002/eet.332.

Parkins, J. R., \& Mitchell, R. E. (2005). Public participation as public debate: A deliberative turn in natural resource management. Society and Natural Resources: An International Journal, 18(6), 529-540.

Pellizzoni, L. (2001). The myth of the best argument: Power, deliberation and reason. The British Journal of Sociology, 52(52), 59-86.
Perreault, T. (2014). What kind of governance for what kind of equity? Towards a theorization of justice in water governance. Water International, 39(2), 233-245. https://doi. org/10.1080/02508060.2014.886843.

Richardson, T. (2015). On the limits of liberalism in participatory environmental governance: Conflict and conservation in Ukraine's danube delta. Development and Change, 46(3), 415-441.

Scolobig, A., Pellizzoni, L., \& Bianchizza, C. (2016). Public participation and trade-offs in flood risk mitigation: Evidence from two case studies in the Alps. Nature and Culture, 11(1), 93-118. https://doi.org/10.3167/nc.2016. 110105

Selin, H., \& Van Deveer, S. D. (2015). Broader, deeper and greener: European Union environmental politics, policies, and outcomes. Annual Review of Environment and Resources, 40(1), 309-335. https://doi.org/10.1146/ annurev-environ-102014-021210.

Smith, H. M. M., Blackstock, K. L. L., Wall, G., \& Jeffrey, P. (2014). River basin management, development planning, and opportunities for debate around limits to growth. Journal of Hydrology, 519(PC), 2624-2631. https://doi. org/10.1016/j.jhydrol.2014.04.022.

Swyngedouw, E. (2005). Governance innovation and the citizen: The Janus face of governance-beyond-the-state. $U r$ ban Studies, 42(11), 1991-2006. https://doi.org/10.1080/ 00420980500279869.

Swyngedouw, E. (2011a). Interrogating post-democratization: Reclaiming egalitarian political spaces. Political Geography, 30, 370-380.

Swyngedouw, E. (2011b). Depoliticized environments: The end of nature, climate change and the post-political condition. Royal Institute of Philosophy Supplement, 69, 253-274.

Valinia, S., Hansen, H. P., Futter, M. N., Bishop, K., Sriskandarajah, N., \& Fölster, J. (2012). Problems with the reconciliation of good ecological status and public participation in the Water Framework Directive. Science of the Total Environment, 433, 482-490. https://doi.org/10. 1016/j.scitotenv.2012.06.087.

Voulvoulis, N., Arpon, K. D., \& Giakoumis, T. (2017). The EU Water Framework Directive: From great expectations to problems with implementation. Science of the Total Environment, 575, 358-366. https://doi.org/10.1016/j. scitotenv.2016.09.228.

Wilson, J., \& Swyngedouw, E. (2014). The post-political and its discontents spaces of depoliticisation, spectres of radical politics. Edinburgh University Press.

Zinzani, A., \& Bichsel, C. (2018). IWRM and the politics of scale: Rescaling water governance in Uzbekistan. Water, 10(3), 281-294.

Publisher's Note Springer Nature remains neutral with regard to jurisdictional claims in published maps and institutional affiliations. 